\title{
Operation of the Handicraft Element of Primary and Junior Secondary Curriculum: Implications for Technological Adavancement in Nigeria
}

\author{
Nath M. Abraham \\ Faculty of Education, University of Port Harcourt \\ Port Harcourt, Nigeria \\ Tel: 234-803-340-9364Ｅ-mail: nathabraham@yahoo.com \\ Lois Nkechi Abraham \\ Faculty of Education, University of Port Harcourt \\ Port Harcourt, Nigeria \\ E-mail: lois2abraham@yahoo.com \\ Mark B. Leigha \\ Faculty of Education, Niger Delta University \\ Wilberforce Island, Amassoma, Bayelsa State, Nigeria \\ E-mail: leighamark@yahoo.com
}

Received: May 2, 2012

doi:10.5430/wje.v2n3p94
Accepted: May 30, 2012

Published: June 15, 2012

\begin{abstract}
Technological advancement has been related to national economic growth and poverty reduction by both national and international analysts. Development of indigenous skills (handicrafts or handiwork) is seen as central to successful administration of indigenous skill development critical for solution of contemporary problems in society. In Nigeria, the desire to develop local craft as a basis for technology appreciation and application is well articulated in the National Policy on Education, especially in the basic (primary and junior secondary) education curriculum. It is expedient therefore, to examine the operation of the handicraft element of the basic education curriculum and determine the implications on the nation's strive to achieve technological advancement. Consequently, relevant terms were conceptualized; the implications for policy operation were treated, and parameters for better operation such as provision of basic infrastructures (libraries, laboratories, workshops, etc), training of local craft teaching staff, in addition to adequate financing were recommended.
\end{abstract}

Keywords: Handicraft element, curriculum, technological advancement.

\section{Introduction}

School education has not only become a world development creed (Okeke, 2004) but also the fastest passport to technological advancement (World Bank, 1995; UNESCO, 2005; UNESCO, 2006). Most industrialized nations of the world (such as Japan, China, Britain, France, USA, etc) attribute their success to a school education development based on science and technology promotion.

A school, to Illich (1975) in Okeke (2004:5), is an "age specific, teacher-related process requiring full - time attendance at an obligatory curriculum". Curriculum gives meaning and identity to operations of school system development. It expresses the heart and soul of the society without which school processes could remain impotent within the context of national ambition prosecution.

In realization of technological competence cruciality to national development, the Federal Republic of Nigeria (2004) avers that modern educational technologies will be increasingly used and improved upon to enhance school operations at all levels of the education system. This move seems appropriate considering the enormous roles assigned to basic (primary and junior secondary) education. For instance, basic primary education is necessary to: 
(i) inculcate permanent literacy and numeracy, and ability to communicate effectively;

(ii) lay a sound basis for scientific and reflective thinking;

(iii) give citizenship education as a basis for effective participation in and contribution to the life of the society;

(iv) mould the character and develop sound attitude and morals in the child;

(v) develop in the child the ability to adapt to the child's changing environment;

(vi) give the child opportunities for developing manipulative skills that will enable the child function effectively in the society within the limits of the child's capacity;

provide the child with basic tools for further educational advancement, including preparation for trades and crafts of the locality.

Its curriculum include: (i) Languages (ii) Mathematics (iii) Science (iv) Physical and Health Education (v) Religious Knowledge (vi) Agriculture/Home Economics (vii) Social studies and Citizenship Education (viii) Cultural and Creative Arts (Drawing, Handicraft, Music and Cultural Activities) (ix) Computer education (FRN, 2004:14).

Similarly, the junior secondary is assigned, broadly, the role of preparing individuals for: (a) useful living within the society; and (b) higher education. In specific terms, it aims, among others, to:

(i) offer diversified curriculum to cater for the differences in talents, opportunities and future riles;

(ii) provide trained manpower in the applied sciences, technology and commerce at sub-professional grades;

(iii) inspire students with a desire for self improvement and achievement for excellence;

(iv) provide technical knowledge and vocational skills necessary for agricultural, industrial, commercial and economic development (FRN, 2004:18-19).

The JSS curriculum for pre-vocational electives include: (i) Agriculture (ii) Business Studies (iii) Home Economics (iv) Local Crafts (v) Computer Education (vi) Fine Art (vii) Music. Emphasis on subjects in this category is "practice" (FRN, 2004: 20).

The above positions effectively suggest that operation of 'handicraft' or local crafts is fundamental to education curriculum development in Nigeria, especially at the basic - primary, as in items (viii) and junior secondary, as in item (iv) - education level. It also suggests a strong desire to build solid foundation for technological advancement in the country to diffuse global standards but sacred operation of these elements in the system still remains.

We live in an era characterized by rapid scientific and technological civilization in which dynamic knowledge becomes crucial to national development much like intellectual giants (USA, Canada, Japan, France, Britain and others) who made science and technology the bedrock of national development (Igwe, 2002; UNESCO, 2006). One of the major challenges of developing countries is how to prepare youths to effectively cope with the global scientific and technological intelligence development.

This development has created two priorities for education system development in Nigeria: it must meet the nation's growing demand for technically competent workers who can readily apply new skills, and it must operate a curriculum to effectively support the sustenance of that knowledge. Consequently, a curriculum development envisioned to operate handicraft elements (weaving, molding, smiting, carving, painting, etc) to initiate, develop and subsequently apply technological competence in the nation's development ambition becomes imperative.

This imperative is in realization of the fact that we live in a world where science and technology have become an integral part of the world culture and any nation that overlooks this significant truism does so at its peril (Fafunwa, 1974).

\section{2. 'Handicraft' conceptualized}

To properly conceptualize this word 'handicraft', it must be essentially broken down to component parts. The two active components are 'hand' and 'craft'. While we are familiar with 'hand' as the terminal part of the human arm used mainly for grasping and performing a lot other jobs, 'craft' needs better conception.

The American Heritage Dictionary of the English language (2000:424) appreciates 'craft' as “skill in doing or making something, as in the arts; proficiency". To Chambers (2001:314), 'craft' is a "skill, trade or occupation, especially one requiring the use of the hands". This definition is consistent with that of Hornby (2005:357), both of which are found appropriate in this discourse. According to him, craft is "an activity involving special skills at making things with your hands". Obvious from the above is that craft is a hand (manual) related proficiency in making something. Hence, 
'handicraft' could be seen as a manual skill in making something using the hands as basic tool and could be taken as a rudimentary attempt at initiating something with the possibility of advancement latter in the process, particularly when planned and administered under the auspices of a school.

\section{What is school Curriculum?}

Curriculum is the 'way-shower' without which a school system would grope in the dark. It is an expression of planned experiences or activities by which educational institutions wish to produce the kind of doctors, lawyers, engineers, nurses, teachers, etc needed to actualize a nation's development strive. School curriculum translates national policy on education into activities or experiences (theory and practice) that promote students learning, so that the goals and objectives of national development are attained (Awotua-Efebo, 1999).

Curriculum is a product of society and reflects its characteristics and trends. It gives meaning and orientation to the school enterprise. School curriculum is a tool by which knowledge, attitudes, skills and values regarded as fundamental to the optimum development of a particular social condition are implanted (Achuonye \& Ajoku, 2003). Such activities or experiences come in form of social interactions between students in workshops; practical offered in laboratories, etc and also include handicrafts.

The school curriculum necessarily relates the value of the past to the present and the future (Awotua-Efebo, 1999) meaning that traditional (or indigenous) ideas, skills and competences are developed, not discarded, to suit contemporary circumstances and needs. Its potentials and proficiencies are refined, redefined and aligned to satisfy modern living standards thus assist to keep the recipient fully integrated to his/her community. In doing so, a curriculum helps realize the goals and organization of the nation as stated in the National Policy on Education; ensure that learning experiences and expectations reflect the physical, intellectual, emotional and other needs of the learner, thus responds to the needs of the society (Ituen, 2004).

Curriculum is critical for educational administration because it provides the focus, direction and basic concerns or specific goals to administer (Edem, 1987). Enaohwo \& Eferakeya (1989) see a curriculum as "the totality of structured contents, methods, and materials, knitted to the learning experiences of students under the direction of the school". Hence, apart from syllabuses and instructional materials, curriculum has to do with the numerous experiences (workshops, practical, techniques, etc) which students need to pass through to qualify as doctors, engineers, nurses, teachers, lawyers, etc to be able to function effectively and add to national development that diffuse global standards. In this light, curriculum becomes a medium through which school expenses relates and closely knit to experiences of the environment and provides integration.

In Nigeria, Basic 1-9 (Primary and JSS) curriculum ambitiously articulate the teaching of 'handicraft' as optional subject, suggesting huge need for technological advancement with global perspectives (Edem, 1987). But, it is when students actually start working on some units of handicraft (weaving, sowing, designing, painting, molding, smiting, fabricating, etc) in the school system that technical advancement intentions could be realized.

\section{Operation of the handicraft element of primary and junior secondary curriculum}

Policies are good intentions until they are put into action (Abraham, 2003). The planned experiences or activities for student training and education in the school system cannot be made functional except they are translated into action or become operational. Quite often in the developing world, including Nigeria, intention of governing authorities to develop programmes remains in theory without actual practice. The recipient finds the normal science and empirical nature inconsistent with their present life-style, attitude and thought (Igwe, 2002). This enterprise does not offer immediate solution to the problems (poverty, hunger, deprivation, diseases, etc) of contemporary society.

The youth, as Azubike (1997) in Igwe (2002) asserts, wants a kind of science and technological education that would make it possible for them to appreciate the worth of the scientific enterprise and use the technology it develops to tackle the existing societal problems (malnutrition, maternal and infant mortality, poverty, etc). It is imperative, he further asserts, that those who are to face the ever-changing problems of the future be equipped with problem solving skills and be drilled in science and technology.

Azubike (1997) must have drawn his analogy from the technological development experiences of great nations (Japan, USA, Canada, Britain, China, etc) where youth initiatives (toys, models, and such other designs) are, not only given adequate prominence but subsequently develop into full blown inventions. Apparently, developed nations invest valuable time and finance into Laboratories, workshops and other related equipment development which transform youth dreams, aspirations, ambitions and such other initiatives into reality thereby making technical studies relevant, provoking, inviting and challenging. 
Such developments raise worry among educational administrators about the pattern of education curriculum development in the country, as Igwe (2002: 64) asks: where do developing countries, Nigeria in particular, "lay emphasis? Does the kind of training given to our future scientists (and technologists) move towards the production of 'revolutionary scientists' or 'normal science adherents?'. This question effectively represents a development gap between priority and practice in curriculum development and suggests the development of a 'home-grown' education rather than developing an "education system (that) is largely colonial" (Anyanwu, 2008:40) or bookish.

Apparently, the UBE scheme is suppose to produce individuals who are masters of their own hands and minds. This is because its handicraft element or:

Non-formal education programmes could be organized for the participants to acquire skills in sewing, batik and tie-dye fabric design, manufacture of mats, aprons, woven sisal handicrafts, cane chairs and tables as well as production of confectionaries. Also, the skills and knowledge of artisans such as mechanics, carpenters, bricklayers, panel beaters and motor spray-painters could be improved in such workshops. Even when the people have acquired various survival skills, they must be exposed to the skills of business management. The training ...should include how to manage bank accounts, stock-taking and general book-keeping (Nwafor, 2006:68).

But what goes on in most UBE schools in the name of handicraft (handwork) is mere payment of representative fees or dues rather than actual handiwork practice which effectively kill youth ingenuity and have serious implications for technical advancement in the country.

\section{The implications}

The fact that science and technology are major propellers in any economy is no longer in doubt (Okali, 2007) but, certain parameters must of necessity establish for technical advancement in the country. To this end, operation of handicraft element in the basic curriculum is central. No system of education achieves great results with its curriculum trapped between fantasy and reality. A nation that plans to be great, yet remain policy fabricators (managers) rather than operators (administrators), "plans what never was and never shall be" (Fafunwa, 2008:13).

The conventional education practice and its empirical nature must find congruence with the present life-style and thought of the citizenry (Igwe, 2002). People want an enterprise that has immediate relevance to the solution of contemporary problems in society. This requires 'democratic practice'- the operation of an indigenous technical culture developed by the people, for the development and advancement of their society as it obtains in developed societies (USA, Britain, Japan, France and others). Operation of the handicraft element in the curriculum seems to be the missing link between policy management and national objective realization.

The lack of proper operation of the handicraft element in the curriculum is increasingly seen to limit Nigeria's ability to pursue effective technological advancement strategies, which leads governments and private funding communities to place increased emphasis on effective administration (FRN, 2004; Igwe, 2002). Delays in operating the handicraft element in the curriculum to keep pace with technical advancement are most apparent in Nigeria's transition economy. Lag in operation can hinder economic growth; conversely, timely operation can pay off in terms of economic growth and poverty reduction, as evidenced in some East Asian, Western European and North American countries that have generally invested heavily in basic education curriculum operation (World Bank, 1995; UNESCO, 2005; UNESCO, 2006).

A curriculum development geared towards "acquiring certificate and degrees" rather than "equipping the citizens to be nation builders" (Anyanwu, 2008:40) does not represent optimal preference to launch the nation on the fast lane of socio-economic prosperity. Moving education towards skill acquisition technologies where recipients would acquire some skills relevant for community life and enable solve the economic problems of contemporary Nigeria (Fafunwa, 2004; Fafunwa, 2008; Anyanwu, 2008) is imperative.

Progress of the Nigerian education development towards home-grown orientation, radically divorced from colonial orientation, seems not in sight (Ebong \& Leigha, 2007; Anyanwu, 2008). This implies that much of the ideas, skills, attitudes, habits, and values acquired are not only those of the British but are unemployable in the Nigerian system to which they are alien. This calls for a structural re-engineering of our education system to be able to produce and utilize our product to effectively solve our peculiar problems (Anyanwu, 2008).

Quite often, the prominence of handicraft is an impetus for technical education development; however the meaning and implications of the term are often too rarely clarified. In most developed countries including the USA, level of curriculum operation is related to educational achievement. Curriculum implementation helps transform and improve ideas, skills, and attitudes which lead to development. Technology improves labour structures, technological innovations, 
capital accumulation, skill acquisition which occasions economic growth and poverty reduction leading to improved living in society.

One could effectively contend that level of technology acquired is proportional to the level of national output achieved. Put differently, the higher the stock of skills and expertise acquired through handicraft operation, the higher the level of productivity acquired by the citizenry. Conversely, level of productivity acquired by the people closely reflects the stock of skills and expertise prevalent in the society which is consequent upon handicraft advancement. This effectively represents the thinking that investment in education (especially technical-based curriculum development) accelerates economic growth (Blaug, 1970; Eze, 1983; World Bank, 2006; UNESCO, 2006; Ebong, 2006).

Though disheartening to learn but, there is wide acceptance that the products of the Nigerian University system do not possess skills enough to be employable (Eze, 1983; Ebong, 2006; Anyanwu, 2008; Fafunwa, 2008). This claim only seems acceptable within the context of 'brain-drain syndrome' in Nigerian. If products of the Nigerian education system possess adequate skills and competence to meet international standards then it could as well be that the system produces 'export standards' rather than 'domestic grade' suggesting that training instrument (curriculum) designs hardly suit domestic demand. Indeed, brain-drain may be an effective representation of curriculum development alienation and requires re-engineering for optimal adaptation.

\section{Conclusion}

Adopting an education development envisioned at achieving technological progress enough to support economic growth and poverty reduction requires the development of an indigenous technical culture. Operation of handicraft element in the curriculum is a drastic move towards achievement of indigenous skill development for solution to socio-economic problems peculiar to Nigeria. A school system succeeds when its programmes and instructions are closely related and viable to the society.

Curriculum is typical for variance in problems, needs and dynamics of society. Hence, moving society towards desired direction, especially in terms of technical advancement, requires establishment of certain variables.

\section{Recommendations}

Based on the above, we recommend as follows:

$>$ Since the school system has deviated from original intentions, there is the urgent need for re-engineering of the curriculum with a view to refine and redefine fundamental objectives and emphasis.

$>$ Part of the problem of poor curriculum operation is attributed to unqualified staff and teaching methods. Hence, there is the need also to train and retrain teachers for effective operation of the handicraft element of the basic education curriculum in line with modern trends.

$>$ It established that most schools operate with few or no requisite facilities hence authorities should ensure that all basic infrastructures (workshops, laboratories, and related equipments) are provided for effective teaching and learning of handicraft in schools.

$>$ Education, in Nigeria, is the most important tool for development and need to be removed from politics. Governing authorities should ensure that technocrats are appointed into educational boards and ministries; and that all relevant education policies and laws are honestly implemented both in letter and in spirit.

$>$ Finally, since all these moves would depend on money, governing authorities should endeavour to implement the $26 \%$ UNESCO annual budget funding of the education sector for optimal support and goal attainment.

\section{References}

Abraham, N. M. (2003). Educational administration in Nigeria. Port Harcort: Pam Unique Publishers

Achuonye, K.A. \& Ajoku, L.I. (2003). Foundations of curriculum development and implementation. Port Harcourt: Pearl Publishers.

Anyanwu, C. (2008). 'Our education system is largely colonial'. Daily Sun. Lagos: The Sun publishing limited.

Awotua-Efebo, E.B. (1999). Effective Teaching- principles and practice. Port Harcourt: Paragraphics.

Blaug, M. (1970). An introduction to the economics of education. London: Penguin books.

Chambers (2001). $21^{\text {st }}$ Century Dictionary (revised edition). New Delhi: Allied publishers private limited. 
Eze, A. (1983). Economics of education- The Nigerian experience. Owerri: New African publishing co. Ltd.

Ebong, J.M. \& Leigha, M.B. (2006). Graduate unemployment in Nigeria: Concept and issues. African Journal of Education and Developmental Studies (AJEDS). 3(1). Pp. 103-111.

Edem, D.A. (1987). Introduction to educational administration in Nigerian. Ibadan: Spectrum Books limited.

Enaohwo, J.O. \& Eferakeya, O.A. (1989). Educational Administration. Ibadan: Paperback publishers limited.

Fafunwa, A.B. (1974). History of education in Nigeria. London: GEORGE ALLEN \& UNWIN.

Fafunwa, A.B. (2004). 'The Education 100'. Tell Magazine. Ikeja, Tell communications Ltd. No 37. p. 53.

Fafunwa, B.A. (2008). ‘A system gone awry’. Tell Magazine. Ikeja: Tell communications Ltd. No. 44. p. 13.

Federal Republic of Nigeria. (2004). National policy on education. Lagos: NERDC press.

Hornby, A.S. (2005). Oxford Advanced Learners' Dictionary. London: Oxford university press.

Igwe, L.E.B. (2002). Introduction to educational administration. Port Harcourt: Global links communications international.

Ituen, S.A.U. (2004). Elements of Teaching. Uyo: Abigab Associates Ltd.

Okali, D. (2007). 'How science and technology education can drive our economy, by Professor Okali'. Daily Sun. Lagos: The Sun publishing limited. p.17.

Okeke, B.S. (2004). Teaching in Nigeria: The bureaucracy and professionalism. Port Harcourt: MERCURY INT'L PUBLISHING NIG.

UNESCO (2005). Education for All-progress and prospect. Paris: UNESCO.

UNESCO (2006). Education for All Global Monitoring Report-Literacy for Life. Paris: UNESCO.

WORLD BANK. (1995). Education and development. Washington DC: World Bank. 